RESEARCH ARTICLE

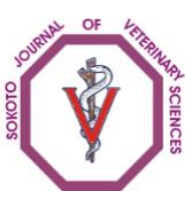

Sokoto Journal of Veterinary Sciences

(P-ISSN 1595-093X/ E-ISSN 2315-6201)

Paul et al/Sokoto Journal of Veterinary Sciences (2016) 14(1): 10-14

http://dx.doi.org/10.4314/sokjvs.v14i1.2

\title{
Gastrointestinal helminths and external parasites of domestic rats trapped from residential areas within Maiduguri Municipality, Nigeria
}

\author{
BT Paul ${ }^{1 *}$, F Kyari $^{2}$, MA Gadzama ${ }^{2}$, MK Zango $^{2}$, EF Ejeh $^{2}$, JJ Ndahi ${ }^{2} \&$ HP Mana $^{1}$ \\ 1. Veterinary Teaching Hospital, University of Maiduguri, Maiduguri, Nigeria. \\ 2. Department of Veterinary Microbiology and parasitology University of Maiduguri, Maiduguri, Nigeria.
}

*Correspondence: Tel.: +2348069594033, E-mail: bpaulgadzama@yahoo.com

\begin{abstract}
A survey of domestic rats was conducted to investigate the prevalence of gastrointestinal helminths and external parasites in Maiduguri municipal between February and June 2015. Rats were randomly collected from residential sites within Maiduguri metropolis by trapping using mechanical and glue board traps. Trapped rats were examined for external parasites, humanely sacrificed and subjected to detailed postmortem examination for recovery of gastrointestinal helminths using standard methods. Parasites were identified using key morphological characteristics. Out of 85 rats sampled in the study, a total of $7(8.2 \%)$ were positive for gastrointestinal helminths. The only species of helminth identified was Hymenolepis diminuta. There was no significant difference in prevalence of gastrointestinal helminths among different age groups and sexes $(P>0.05)$. The overall prevalence of ectoparasites was $9.4 \%$ and there was no significant difference in prevalence rates among different age groups and sexes $(P>0.05)$. The prevalence of flea (5.9\%) was higher than lice (3.5\%). The two species of ectoparasites identified in the study were Ctenocephalides canis (5.9\%) and Polyplax spinulosa (3.5\%). It was concluded from this study that domestic rats trapped from Maiduguri harbor some species of endoparasites and ectoparasites which are potentially zoonotic or may serve as vectors of important zoonotic pathogens.
\end{abstract}

Keywords: Domestic rats, Ecto-parasites, Gastrointestinal helminths, Maiduguri, Prevalence

Received: 25-08- 2015

Accepted: 10-02-2016

\section{Introduction}

Rats are various medium-sized, long tailed rodents of the super family Muroidea. The true rats belong to the genus Rattus, the most important species to man being the black rat, and the brown rats (Hilton et al., 2010). These two species are the commonest and often live as opportunistic survivors in close association to man (Solanki et al., 2013). In many parts of the world, rat meat is a special delicacy that provides rich source of protein (Fielder, 1990). Rats have also been known to harbor potentially zoonotic microbes such as bacteria, viruses, helminths, protozoa and rickettsiae (Soulsby, 1982). Domestic rats are established reservoirs of bubonic plague and Lassa fever virus which are highly pathogenic hemorrhagic fevers of man (Service, 1980). Other diseases known to be transmitted to man by commensal rats include trichinellosis, capillariosis, leptospirosis, salmonellosis, Hanta virus disease, murine typhus and Crimean Congo hemorrhagic fever (Sharma \& Kumar, 2008).

The prevalence and importance of external and gastrointestinal parasites of domestic rats has been reported by various authors working independently in different parts of the world. Solanki et al. (2013) reported an overall prevalence of $18 \%$ for ectoparasites in domestic rats in India. Stojcevic et al. (2004) reported $65.1 \%$ prevalence of ectoparasites in domestic rats in Croatia. In Nigeria, Ogunniyi et al. (2014) reported $38.0 \%$ prevalence of Xenopsylla cheopis and 58.0\% prevalence of helminths in a survey of domestic rats in Ibadan. Domestic rats have been recognized as serious pests to agricultural crops and domestic furniture throughout the world and their infestations accounts for a significant reduction in agricultural crop yield (Hilton et al., 2010). Domestic rats are also recognized as reservoir 
hosts of important parasitic diseases for man, wild and domestic animals. They often live in close association with man, often feeding on the same food and water source, which may be contaminated with their droppings. In addition, their bites and bites of their ectoparasites may serve as a medium for transmission of pathogens to man. The objective of this survey was to investigate the occurrence of gastro-intestinal helminths and ectoparasites in domestic rats in Maiduguri, Borno State.

\section{Materials and Methods}

Study area

This study was carried out in Maiduguri, the capital of Borno state, North Eastern Nigeria. Maiduguri is located between latitudes $11^{\circ}$ and $14^{\circ} \mathrm{N}$ and longitudes $10^{\circ}$ and $14^{\circ} \mathrm{E}$, with an average population density of 1,738 people per square kilometer and a total population of 521,493 people (NPC, 2006). The mean annual temperature ranges between $34-40^{\circ} \mathrm{C}$ for most parts of the year, with a mean annual rainfall of $647 \mathrm{~mm}$ (LCRI, 2007).

\section{Study population}

The rats used for this study were domestic rats of both sexes in residential areas within Maiduguri Municipality.

\section{Study design}

Eighty five live rats were captured by using mechanical baited and sticky glue board traps in selected locations within Maiduguri Metropolitan Council Area and Jere. These were placed in plastic containers covered with wire mesh and transported to the Veterinary Parasitology Laboratory, University of Maiduguri for parasitological examinations.

\section{Collection and identification of ectoparasites}

Individual rats were grossly examined and with the aid of hand lens, for presence of external parasites like ticks, fleas and lice. This was followed by hand picking where possible; the use of forceps and careful brushing of the hairs onto a sheet of paper to collect parasites. All ectoparasite specimens were preserved in $50 \%$ ethanol until processed for morphological identification. Ectoparasites were first relaxed, dehydrated in $70 \%$ alcohol and mounted on glass slides using the methods of Soulsby (1982) and examined under a dissecting microscope for morphological identification using key features described by Soulsby (1982).

\section{Parasitological examinations}

Trapped rats were euthanized according to standard procedures (Leary et al., 2013) and subjected to standard post-mortem examination (Fiette \& Slaoui, 2011) to collect the gastrointestinal tract for worm recovery and identification. A detailed examination of each gastrointestinal tract was performed as described by Okorafor et al. (2012). Each gastrointestinal tract was spread out on a dissecting board and opened up through a longitudinal incision using a scalpel blade to expose the luminal content which was then emptied onto a petridish containing normal saline $(0.9 \% \mathrm{NaCl})$. The mucosal wall of the gastrointestinal tract was gently scraped with blunt scalpel and washed in saline to remove tiny worms in the lining. The mixture was then examined on a petridish under the dissecting microscope and microscopic worms were then removed using forceps for further processing. These were mounted on glass slides using the method of Soulsby (1982) and identified using key morphological features described in earlier studies by Okorafor et al. (2012).

\section{Statistical analysis}

Data on age, sex and those obtained during laboratory examinations of rats were summarized in Microsoft Excel Spread Sheet. 2007 version and presented in tables using descriptive statistics. Prevalence was estimated as $P=d / n(\%)$; where $P=$ prevalence, $d=$ number of individuals having disease at a particular point in time and $n=$ number of individuals in the population at risk at that point in time (Thrusfield, 2005).

Table 1: Overall prevalence of gastrointestinal helminths of domestic rats in Maiduguri

\begin{tabular}{lll}
\hline Variable & $\begin{array}{l}\text { No. } \\
\text { Examined }\end{array}$ & $\begin{array}{l}\text { No. (\%) } \\
\text { Infected }\end{array}$ \\
\hline Sex & & \\
Male & 34 & $4(4.7)$ \\
Female & 51 & $3(3.5)$ \\
Age & & \\
Young & 39 & $1(1.1)$ \\
Adult & 46 & $6(7.1)$ \\
Overall & 85 & $7(8.2)$ \\
\hline
\end{tabular}


Table 2: Overall Prevalence of Ectoparasites of Domestic Rats in Maiduguri

\begin{tabular}{lll}
\hline Variable & $\begin{array}{l}\text { No. } \\
\text { Examined }\end{array}$ & $\begin{array}{l}\text { No. (\%) } \\
\text { Infected }\end{array}$ \\
\hline Sex & & \\
Male & 34 & $4(4.7)$ \\
Female & 51 & $4(4.7)$ \\
Age & & \\
Young & 39 & $3(3.5)$ \\
Adult & 46 & $5(5.9)$ \\
Overall & 85 & $8(9.4)$ \\
\hline
\end{tabular}

Table 3: Prevalence of various species of ectoparasites in domestic rats in Maiduguri

\begin{tabular}{lcc}
\hline Species & $\begin{array}{c}\text { No. } \\
\text { Examined }\end{array}$ & $\begin{array}{c}\text { No. (\%) } \\
\text { Infected }\end{array}$ \\
\hline Lice & 85 & $3(3.5)$ \\
Flea & 85 & $5(5.9)$ \\
Total & 85 & $8(9.4)$ \\
\hline
\end{tabular}

\section{Results}

The overall prevalence of gastrointestinal helminths of domestic rats in Maiduguri is presented in Table 1 . Out of 85 rats examined in the study, 7 (8.2\%) were positive for helminth infection. The prevalence of helminths was higher in adult (7.1\%) than young (1.1\%) rats. Hymenolepis diminuta was the only species of gastrointestinal helminth parasite identified in this study. The overall prevalence of ectoparasites of domestic rats in Maiduguri is presented in Table 2. Out of a total 85 rats sampled in the study, 8 (9.4\%) were positive for one species of ectoparasites or the other. Prevalence of ectoparasites in both male and female rats was the same (4.7\%). Adult rats had a higher prevalence (5.9\%) compared with younger rats (3.5\%). The prevalence of various species of ectoparasites recovered from domestic rats in Maiduguri is presented in Table 3 . Out of 85 rats sampled in the study, 3(3.5\%) were infested with lice while $5(5.9 \%)$ were infested with fleas. The species of flea identified in this study was Ctenocephalides canis and the species of lice identified was Polyplax spinulosa.

\section{Discussion}

The results obtained from this study indicate an overall prevalence of $8.2 \%$ for gastrointestinal helminth parasites recovered from trapped domestic rats in Maiduguri. Generally, rodents have high predisposition to gastrointestinal parasites due to their euryphagic food habits (Okorafor et al. 2012). Therefore, the recovery of helminths from domestic rats sampled in this study is not an unusual finding, because rodents are ubiquitous animals and have a fundamental role in the epidemiology of several diseases, including parasitic zoonoses (Marques \&
Scroferneker, 2003). This present findings does not agree with Okorafor et al. (2012) who reported $100 \%$ prevalence of gastrointestinal helminths in wild cane rats captured in Oyo state, Nigeria. Their finding was linked to the mode of life of cane rats (grass cutter) which are exclusively wild in habitat, feeding mainly on pasture contaminated with human and domestic animal wastes. This increases the risk of infection with parasites generally and helminths in particular when compared with domestic rats, which essentially feed on food remnants, grains and vegetable gardens with lesser contamination. Moreover, local differences in prevalence of parasitic helminths was previously reported and linked to differences in local ecological conditions influencing the epidemiology of parasites (Soulsby, 1982; Shah-Fischer \& Say, 1989). The current study identified Hymenolepis diminuta as the only species of tapeworm recovered from domestic rats in Maiduguri. This finding is in agreement with Stojcevic et al. (2004) who reported that $H$. diminuta is the most frequently encountered species of helminth in rats. The role of rodents as reservoirs of important parasitic zoonoses, including $H$. diminuta was reported by Sumangali et al. (2011). The zoonotic potential of Hymenolepis diminuta was also previously reported in the United States, where it was associated with gastrointestinal disorders, mainly in children (Marques \& Scroferneker, 2003).

In the current study we recorded an overall prevalence of $9.4 \%$ for ectoparasites recovered from domestic rats in Maiduguri. This finding does not agree with previous reports by Stojcevic et al. (2004) who reported $32.2 \%$ prevalence of ectoparasites in a survey of rats trapped in rural 
regions of Croatia, Okorafor et al. (2012) who reported $28 \%$ prevalence of ectoparasites in cane rats from Oyo state in Nigeria and Ogunniyi et al. (2014) who reported $38 \%$ prevalence of ectoparasites in peridomestic house rats in lle-ife, Nigeria. The differences in findings could be attributed to local differences in ecological conditions in the study sites. Local differences in prevalence of external parasites have been reported and were linked to differences in local ecological conditions influencing the epidemiology of parasites (Soulsby, 1982; Shah-Fischer \& Say, 1989).

The occurrence of Ctenocephalides canis in domestic rats is not an unusual finding, because fleas are generally not highly host specific and could parasitize other host species to obtain a meal in the absence of a natural host (Soulsby, 1982; Agbede, 2013). This finding agrees with Zahedi et al. (1996) who recovered Ctenocephalides felis from urban rats in Lampur city, Malaysia. This finding was linked to the fact that most urban rats feed in gardens and the surroundings of the houses where dogs frequent. The identification of rat louse Polyplax spinulosa in domestic rats in the current study agrees with Stojcevic et al. (2004), Pakdad et al. (2012) and

\section{References}

Agbede RIS (2013). A Guide to Tropical Veterinary Entomology. MacChin Multimedia Designers, Zaria, Nigeria. Pp 108.

Fielder LA (1990). Rodents as food source Proceedings of the fourteenth Vertebrate Pest Conference Paper 30. http://digital commons.unl.edu/Vpc14/30, retrieved 08-08-2015.

Fiette L \& Slaoui M (2011) Necropsy and sampling procedures in rodents. Methods in Molecular Biology. 691: 39-67.

Hilton AC, Willis RJ \& Hickie S J (2010). Isolation of Salmonella from urban wild brown rats (Rattus norvegicus) in West Midlands, UK. International Journal of Environmental Health Research, 12(2):163-168.

Lake Chad Research Institute (LCRI) (2007). Annual Weather Report, IFAD-TAG, No 718. Pp 28.

Leary S, Underwood W, Anthony R, Cartner S, Corey D, Grandin T, Greenacre C, Gwaltney-Brant S, McCrackin MA, Meyer R, Miller D, Shearer J \& Yanong R, (2013). AVMA Guidelines for the Euthanasia of Animals: 2013 Edition. American Veterinary Medical Association, Schaumburg, IL. Pp 102.

Luyon HAV \& Salibay CC (2007). Ectoparasites on murid rodents caught in MTS Palay-
Luyon \& Salibay (2007) who reported that Polyplax spinulosa is the most frequently encountered species of ectoparasite in rats.

It was concluded from this study that domestic rats trapped from Maiduguri harbor some species of endoparasites and ectoparasites which are potentially zoonotic or may serve as vectors of important zoonotic pathogens. It is therefore recommended that a sound rodent control program be instituted in residential areas to minimize breeding of rodents. Such measures could include proper sanitation, proper waste disposal, use of rodenticides and blocking the access of rodents to residential quarters.

There is also need for further studies on the structure of the rodent population and the mechanisms by which they transmit disease to humans and animals in the study area in order to understand the risk and minimize spread of such diseases by instituting appropriate control measures.

\section{Acknowledgement}

The authors are grateful to Mallam Ali Mohammed and Ya'uba Alhaji Mohammed in the Department of Veterinary Microbiology and Parasitology University of Maiduguri for their technical support.

Palay/Mataas Na Gulod National Park, Luzon Island, Philippines. Southeast Asian Journal of Tropical Medicine and Public Health, 38(1): 194-202.

Marques TMS \& Scroferneker ML (2003). Gastrointestinal helminth parasites of the black rat (Rattus rattus) in a coal mine in Minas do Leao, Rs, Brazil. Revista de Ciencias Agroveterinarias, Lages, 2(2):140-142.

NPC (2006). Nigerian National Population Census Report. National Population Commission, Abuja. Pp 109.

Ogunniyi T, Balogun H \& Shasanya B (2014). Ectoparasites and Endoparasites of peridomestic house-rats in Ile-Ife, Nigeria and Implication on human health. Iranian Journal of Parasitology, 9(1): 134-140.

Okorafor $K A$, Odaibo $A B$, Eleng IE \& Okete JA (2012) Occurrence and prevalence of ecto- and gastrointestinal parasites in wild cane rats (Tryonomys swinderianus) from Oyo State, South- Western Nigeria. European Journal of Zoological Research, 1(3): 70-76.

Pakdad K, Ahmadi NA, Aminalroaya R, Piazak N \& Shaahmehri M (2012). A study of rodent ectoparasites in the North district of 
Tehran, Iran during 2007-2009. Journal of Paramedical Sciences, 3(2): 42-46.

Service MW (1980) A Guide to Medical Entomology. The Macmillan Press Ltd, London. Pp 226.

Shah-Fischer M \& Say R (1989). Manual of Tropical Veterinary Parasitology.CAB International: The Technical Center for Agricultural and Rural Cooperation (CTA), Nairobi, Kenya. Pp 351-363.

Sharma KS \& Kumar K (2008) Entomological surveillance for rodent and their ectoparasites with special reference to potential of scrub typhus at Kolkata Port Trust (KPT), Kolkata (India). Journal of Paramedical Sciences, 5(2):1-6.

Solanki KS, Rashmi C, Rahman A \& Solanki K (2013) Prevalence of ectoparasites of commensal rats in Dehradun, India. International Journal of Current Microbiology and Applied Sciences, 2(4):38-41.

Soulsby EJL (1982) Helminths, Arthropods and Protozoa of Domesticated Animals,
Seventh edition. Bailliere Tindall, London, UK. Pp 809.

Stojcevic D, Maihaljevic Z \& Marinculic A (2004) Parasitological survey of rats in rural regions of Croatia. Veterinarni Medicina Czech, 49(3):70-74.

Sumangali K, Rajapakse RPVJ \& Rajakaruna RS (2011) Urban rodents as potential reservoirs of zoonoses: A parasitic survey in two selected areas in Kandy district. Ceylon Journal of Bioscience, 41(1):71-77.

Thrusfield MV (2005) Veterinary Epidemiology. third edition. Blackwell Science Oxford, London, UK. Pp. 483.

Zahedi M, Jeffery J, Krishnasamy K \& Bharat VK (1996) Ectoparasites of Rattus rattus Diardii from Kuala Lampur City Malaysia, Proceedings of the Second International Conference on Urban Pests, (KB Wildey, editor). $\mathrm{Pp} 3$. 